\title{
The role of multigelation in the development of river banks
}

\author{
Karol AUGUSTOWSKI ${ }^{1^{*}}$ \\ ${ }^{1}$ Pedagogical University of Krakow, Poland \\ * Correspondence to: Karol Augustowski, Department of Physical Geography, Pedagogical University of Krakow, Podchorążych \\ 2, 30-084 Kraków, Poland. E-mail: kaugustowski@wp.pl.
}

\section{O GEOREVIEW}

\section{Article history}

Received: April 2013

Received in revised form: July

2013

Accepted: August 2013

Available online: September 2013

\begin{abstract}
The development of river banks is conditioned by a few factors: fluvial erosion, mass movements and subaerial processes. Many researchers believe that the subaerial phenomena are more preparatory processes to actual erosion than the erosion itself. Among the subaerial phenomena, freezing and thawing play a key role. Multigelation affects the stability and sustainability of river banks, not only in the northern reaches of Eurasia and North America but also in temperate latitudes. Susceptibility to change in bank morphology, however, is extremely selective. Within the same layer, at a distance of 1 metre the intensity of frost erosion can be very different. This is the result of many factors determining the rate of bank retreat. These include: the height of the bank, its structure and texture, physical and chemical properties of the material from which it is built, environmental conditions, soil moisture, water pressure in the pore spaces, porosity and density of the soil, organic matter content in the soil, temperature, vegetation, as well as thickness and duriation of snow cover. An important objective is therefore to show the differences in the rate of retreat of the river banks, and above all characterized by varying degrees of density and grain size of the material it is built of.
\end{abstract}

\section{Introduction}

The development of streambanks is mainly conditioned by three factors: the activity of flowing water and rainwater, mass movements and subaerial processes (Hooke, 1979; Thorne, 1982; Lawler, 1992, 1995; Lawler et al. 1997; Couper and Maddock, 2001; Wynn and Mostaghimi, 2006). The importance of the first two factors appears to be obvious. Subaerial processes are often treated more as preparatory for the actual erosion (due to a loosening of the material including frontal part of the river banks and slopes) than the erosion itself (e.g. Wolman, 1959; Thorne, 1990; Green et al., 1999; Couper, 2003). Subaerial processes are the result of local climate and mainly include: drying, wetting, freezing and thawing (Wynn et al., 2008). The last two of them seem to play a dominant role (Teisseyre, 1984; Lawler et al. 1997).

The rate of retreat of riverbanks depends on many factors. The two most important are: particle size (Wolman, 1959; Schumm, 1960; Walker et al., 1987) and moisture conditions (Thorne and 
Osman, 1988; Dietrich and Gallinatti, 1991; Thorne, 1992) as well as the physical state of this moisture (Thorne, 1990). Other factors include: bank size, bank structure and texture, physical and chemical properties of the bank material (Coffman, 2009), porosity and density of the soil shear strength, organic matter content, chemical properties of pore water, the Atterberg limits, environmental conditions, temperature, water pressure in the pore spaces, vegetation, as well as thickness and length of snow cover (Thorne, 1982; Grissinger, 1982; Allen et al., 1999; Knapen et al., 2007).

Non-cohesive soils erode in a different way than cohesive soils. In addition, other physical and chemical properties in different soil types affect the amount of erosion (Grissinger, 1982; Coffman, 2009). In many cases the non-cemented material eroded as a result of separation of individual soil particles. Cohesive material exhibits more cumulative erosion (Coffman, 2009). Raudkivi (1990), after Coffman (2009), shows that the erosion of soil containing less than $10 \%$ of clay depends entirely on its grain-size distribution. Erosion of river banks resulting from frost action may occur in different ways: needle ice formation, as well as small ice lenses arranged in parallel (or in a direction close to parallel) in relation to the bank face. Change in water volume during multigelation causes loosening of bonds between soil particles, leading to separation of its fragments. The important role is also played by groundwater seepage within the boundary walls. This increases the plasticity of snow deposited on the walls and allows the development of slides (snow, clay and gravel material cemented together).

\section{Methodology}

Bank erosion studies are commonly carried out using one of three methods: erosion pins, (Wolman, 1959; Haigh, 1977; Hooke, 1979,1980; Thorne and Tovey, 1981; Lawler, 1993; Saynor et al., 1994; Casagli et al., 1999; Couper and Maddock, 2001; Couper et al., 2002; Zaimes et al., 2005; Hupp et al., 2009), multiple time-series photogrammetry (Wallick et al., 2006; Larsen et al., 2006) and cross-section surveying (Larsen et al., 2006). The last two methods are difficult because of the lack of adequate resolution and temporal distribution of the obtained data (Coffman, 2009). Therefore, the most popular and easiest to use is the method of erosion pins. Over time it has been extended to the method of PEEP - Photo-Electronic Erosion Pins (Lawler, 1991; Prosser et al., 2000; Couper and Maddock, 2001; Couper et al., 2002; Mitchell et al., 2003; Saynor and Erskine, 2006; Keesstra et al., 2009; McDermott and Sherman, 2009; Hancock et al., 2010), and later to the method of PEEP 3T - Photo-Electronic Erosion Pins with Thermal Consonance Timing (Lawler, 2008). Both methods are aimed at a more effective study of fluvial erosion based on a continuous measurement. The original method of erosion pins is focused on the measurement of specific moments of observation.

\section{Study area}

To determine the importance of frost processes in the development of riverbanks, erosion pins were installed within the riverbanks in four study areas in the Polish Carpathians (fig. 1, tab. 1). The sites were selected based on the variability of cohesion and grain-size of the bank material. 


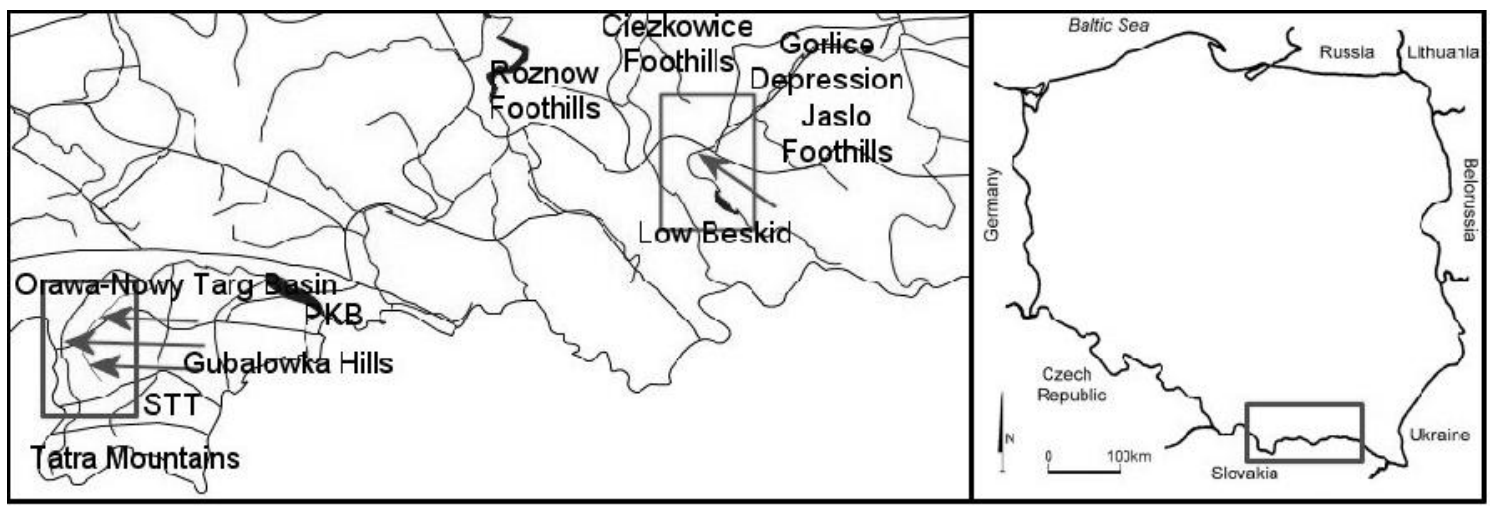

Figure 1. The study areas

The study was conducted during one autumn-spring period in $2010 / 2011$. The number of field observations was determined by the periods of multigelation at particular sites. In the basin of the upper Dunajec River (areas 1-3) observations were carried out five times (early January, midFebruary, early March, late March/April, mid-April); in the Ropa Basin (area 4) - four times (early January, mid February, early March, late March/April).

Table 1. The study areas

\begin{tabular}{ccccc}
\hline Study area & Location & Stream/River & Geology & No of erosion pins \\
\hline 1 & Gubałowka Hills & Cichy & $\begin{array}{c}\text { Flysch } \\
\text { (sandstone/shale) }\end{array}$ & 2 \\
\hline 2 & $\begin{array}{c}\text { Orava-Nowy } \\
\text { Targ Basin }\end{array}$ & Cichy & $\begin{array}{c}\text { strongly cemented } \\
\text { Neogene gravels }\end{array}$ & 6 \\
\hline 3 & $\begin{array}{c}\text { Orava-Nowy } \\
\text { Targ Basin }\end{array}$ & $\begin{array}{c}\text { Czarny } \\
\text { Dunajec }\end{array}$ & $\begin{array}{c}\text { weakly cemented clay } \\
\text { and gravel }\end{array}$ & 7 \\
\hline 4 & Beskid Niski Mts & Ropa & clay /gravel & 6 \\
\hline
\end{tabular}

\section{Results}

\section{Ciche}

The site is located on the right bank of the Cichy Stream. The river bank is built of monoclinally positioned Podhale flysch. The bank undercut ( $3 \mathrm{~m}$ high $\times 3,5 \mathrm{~m}$ wide) consists mostly of thin layers of shale and silt separated by a single layers of thin- $(3-5 \mathrm{~cm})$ and thick-bedded $(30 \mathrm{~cm})$ sandstones - (fig. 2A). The sandstones are fine-grained with a dense network of transverse and oblique fractures.

The density of cracks is definitely higher within the thin shale layers. The presence of such a dense network of cracks creates favourable conditions for circulation of water, predisposing the bank to the increased intensity of frost action. The bank is more steep (almost vertical) and partly vegetated. 

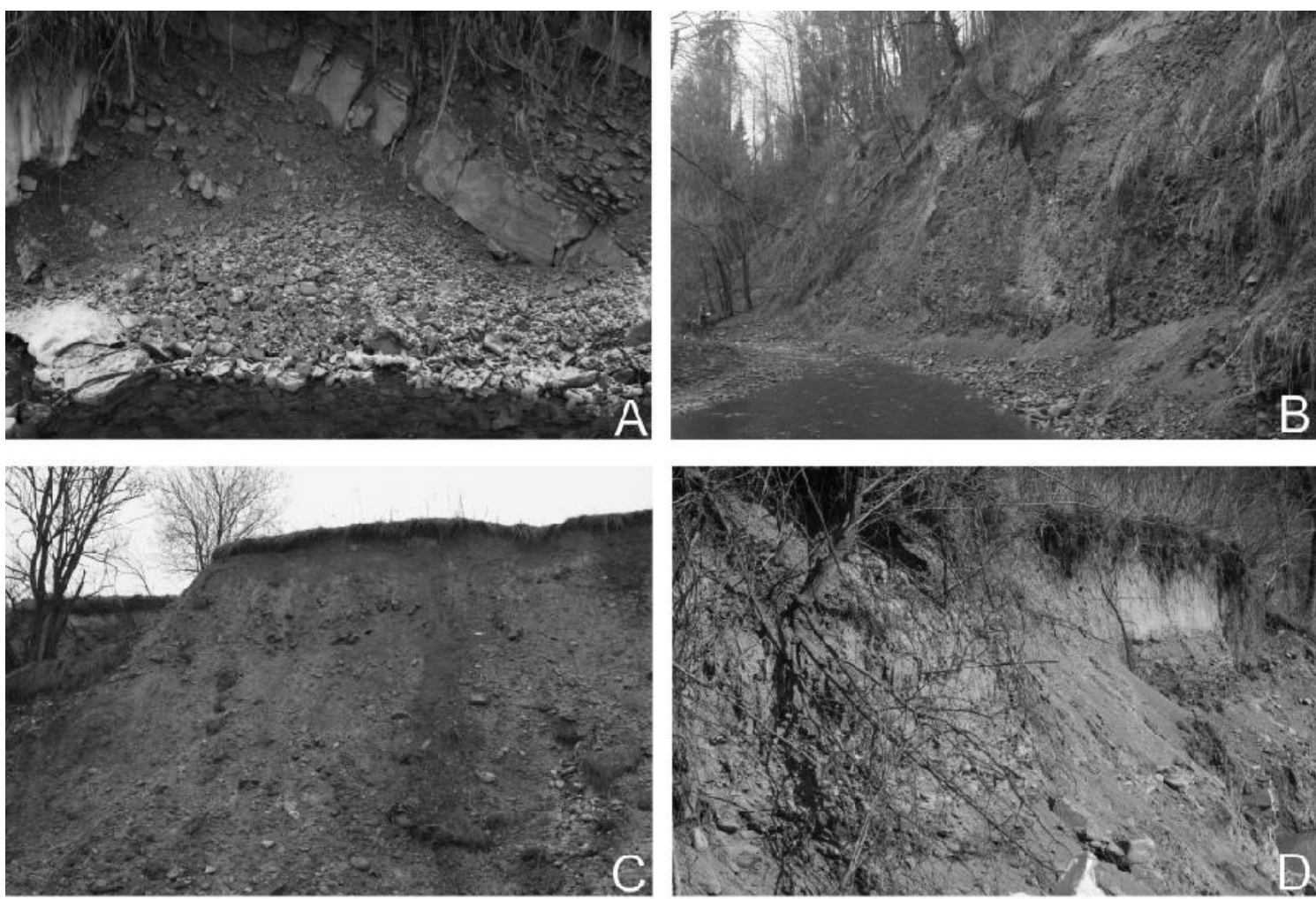

A - Cichy stream, village Ciche; B - Cichy stream, village Stare Bystre

C - Czarny Dunajec river, village Chocholow; D - Ropa river, village Szymbark

Figure 2. Research sites in the basin of the Ropa and Dunajec

During the first period of multigelation erosion affected only the shale material. Shale debris that accumulatedat the base of the bank was similar in size. Only a few particles had diameters larger than $10 \mathrm{~cm}$. Also the volume of talus material was rather small and in early January amounted to $0.1 \mathrm{~m}^{3}$. Erosion pins in this period did not show major changes (tab. 2). A change of $3 \mathrm{~cm}$ was recorded.

During the subsequent period of multigelation the amount of talus material doubled. Between these periods, the debris material was covered by snow. The volume of the accumulation amounted to about $0.2 \mathrm{~m}^{3}$. There were also isolated fragments of sandstone, with dimensions of up to $10 \times 5 \times 5 \mathrm{~cm}$. The material has not been significantly sorted, because residual foot bank face creates cone-shaped taluses. The finest particles accumulated in the upper parts of the cones, and the coarser in the lower sections. Bank retreat, observed on the measurement pins considerably increased. The first of the rods was exposed by $38.2 \mathrm{~cm}$ and the other at a distance of $2.5 \mathrm{~cm}$. In early March there was a change in grain-size of the material deposited at the base of the bank (in cones). The number of large fragments of sandstone significantly increased, to 5 - 20 $\mathrm{cm}$, with the largest fragments even reaching $35 \times 10 \times 10 \mathrm{~cm}$. The previously visible particle sorting (by size) disappeared. However, sorting by weight was still more pronounced as the shale fragments remained in the upper parts of the taluses. The pins were further exposed by $39.4 \mathrm{~cm}$ and $6.9 \mathrm{~cm}$. In the fourth period of observation, in March and April, rocky riverbank retreated further and the volume of the removed material was approximately $0.8 \mathrm{~m}^{3}$. Nearly $70 \%$ of these were mostly (70\%) slate fragments, sized $2-3 \mathrm{~cm}$. The rest were crushed sandstones of varying 
size. The dimensions of the largest sandstone particles were $65 \times 20 \times 15 \mathrm{~cm}, 60 \times 20 \times 10 \mathrm{~cm}$ and $35 \times 20 \times 15 \mathrm{~cm}$. The material was deposited at the base of the bank, randomly, without sorting, except for the biggest particles that accumulated in the lowest parts of the cones. Maximum depth of the cavities that formed on the bank surface was $20 \mathrm{~cm}$. The biggest change occurred in thick layers of sandstone. Breaking off of the blocks occurred along the cracks. The size distribution and the location of this material was confirmed with the sizes and rates recorded at the pins from the retreating bank surface. The first of the pins came out by about $52 \mathrm{~cm}$ and dropped out of the rocky slope, the second was uncovered by $9.2 \mathrm{~cm}$. This reflects the uneven shifting of slope surface. In the last period of multigelation (mid-April) the volume of material deposited at the foot of the slope did not change. Only a part of the material, mostly finer particles, was moved by gravity onto the river bed. The remaining pin slipped a further $0.8 \mathrm{~cm}$ (by $10 \mathrm{~cm}$ in the whole study period).

Table 2. Changes in ejection of erosion pins in subsequent periods of multigelation

\begin{tabular}{|c|c|c|c|c|c|c|c|c|c|c|}
\hline & \multirow{2}{*}{\multicolumn{2}{|c|}{$\begin{array}{l}\text { Multigelation period / } \\
\text { Pin No. }\end{array}$}} & \multicolumn{7}{|c|}{$\begin{array}{l}\text { Changes in the ejection of erosion pins } \\
{[\mathrm{mm}]}\end{array}$} & \multirow{2}{*}{$\begin{array}{c}\text { Cubature } \\
{\left[\mathrm{m}^{3}\right]}\end{array}$} \\
\hline & & & 1 & 2 & 3 & 4 & 5 & 6 & 7 & \\
\hline \multirow{5}{*}{$\begin{array}{l}\text { 1st study site } \\
\text { Ciche }\end{array}$} & 1 & early January & 30 & 0 & & & & & & 0,1 \\
\hline & 2 & mid February & 382 & 25 & & & & & & 0,2 \\
\hline & 3 & early March & 394 & 69 & & & & & & 0,7 \\
\hline & 4 & late March / April & 520 & 92 & & & & & & 0,8 \\
\hline & 5 & mid April & 520 & 100 & & & & & & 0,8 \\
\hline \multirow{5}{*}{$\begin{array}{l}\text { 2nd study site } \\
\text { Stare Bystre }\end{array}$} & 1 & early January & 0 & 0 & 0 & 0 & 0 & 0 & & 0,5 \\
\hline & 2 & mid February & 0 & 0 & 0 & 0 & 0 & 0 & & 0,5 \\
\hline & 3 & early March & 0 & 0 & 5 & 5 & 0 & 0 & & 3 \\
\hline & 4 & late March / April & 0 & 0 & 5 & 5 & 0 & 0 & & 4 \\
\hline & 5 & mid April & 0 & 0 & 5 & 5 & 0 & 0 & & 6 \\
\hline \multirow{5}{*}{$\begin{array}{l}\text { 3rd study site } \\
\text { Chochołów }\end{array}$} & 1 & early January & -40 & -56 & -62 & -87 & -102 & -96 & -91 & 1 \\
\hline & 2 & mid February & -45 & -62 & -59 & -92 & -98 & -103 & -88 & 4 \\
\hline & 3 & early March & 330 & 300 & 412 & 550 & 532 & 375 & 486 & 11,5 \\
\hline & 4 & late March / April & 443 & 431 & 526 & 678 & 675 & 521 & 599 & 12,5 \\
\hline & 5 & mid April & 598 & 754 & 800 & 800 & 800 & 760 & 781 & 13 \\
\hline \multirow{4}{*}{$\begin{array}{l}\text { 4th study site } \\
\text { Szymbark }\end{array}$} & 1 & early January & 10 & 12 & 4 & 24 & 22 & 33 & & 0,1 \\
\hline & 2 & mid February & 13 & 24 & 12 & 43 & 30 & 49 & & 0,1 \\
\hline & 3 & early March & 145 & 198 & 154 & 191 & 183 & 190 & & 0,2 \\
\hline & 4 & late March / April & 224 & 294 & 245 & 311 & 235 & 342 & & 0,5 \\
\hline
\end{tabular}

\section{Stare Bystre}

The second studied bank is also located on Cichy Stream. It is built with firmly cemented gravels and sands, practically devoid of fine cracks, with only few gaps (fig. 2B). This bank is a large outcrop, 15 metres high and 40 metres wide. The high cementation of the sediment and scarcity of cracks make the bank less prone to frost action.

Changes observed in the second study area were rather insignificant. In the first two multigelation periods bank erosion was not observed at all (tab. 2). The pins showed no sliding. In the third period, some material, with a clear dominance of the finest, $2-3 \mathrm{~cm}$ gravel and sand, 
appeared at the foot of the bank taluses. Volume of the deposited material was approximately 3 $\mathrm{m}^{3}$. Erosion pins showed no major changes. Two were ejected by about $0.5 \mathrm{~cm}$. In the fourth period, the volume of deposited material increased to $4 \mathrm{~m}^{3}$, and the share of the pebble-sized gravel also increased. The position of erosion pins did not change. In the last multigelation period, the volume of the material increased to approximately $6 \mathrm{~m}^{3}$. The debris was dominated by pebbles $(5-10 \mathrm{~cm}$ in diameter)

\section{Chochołów}

The third site is located on the left $12 \mathrm{~m}$ high bank of the Czarny Dunajec River. The bank is composed of three layers. The upper part is built with silty clay material $(1 \mathrm{~m}$ thick) beneath which is a thick layer of gravel $(3 \mathrm{~m})$. These two layers are situated on a high base $(8 \mathrm{~m})$ built with Neogene shale and clay material. Layers of clay and gravel are poorly cemented and are characterized by a dense system of fissures and cracks. Between clay and gravel, groundwater seepage occurs (fig. 2C). The bank base is at average water levels of Czarny Dunajec.

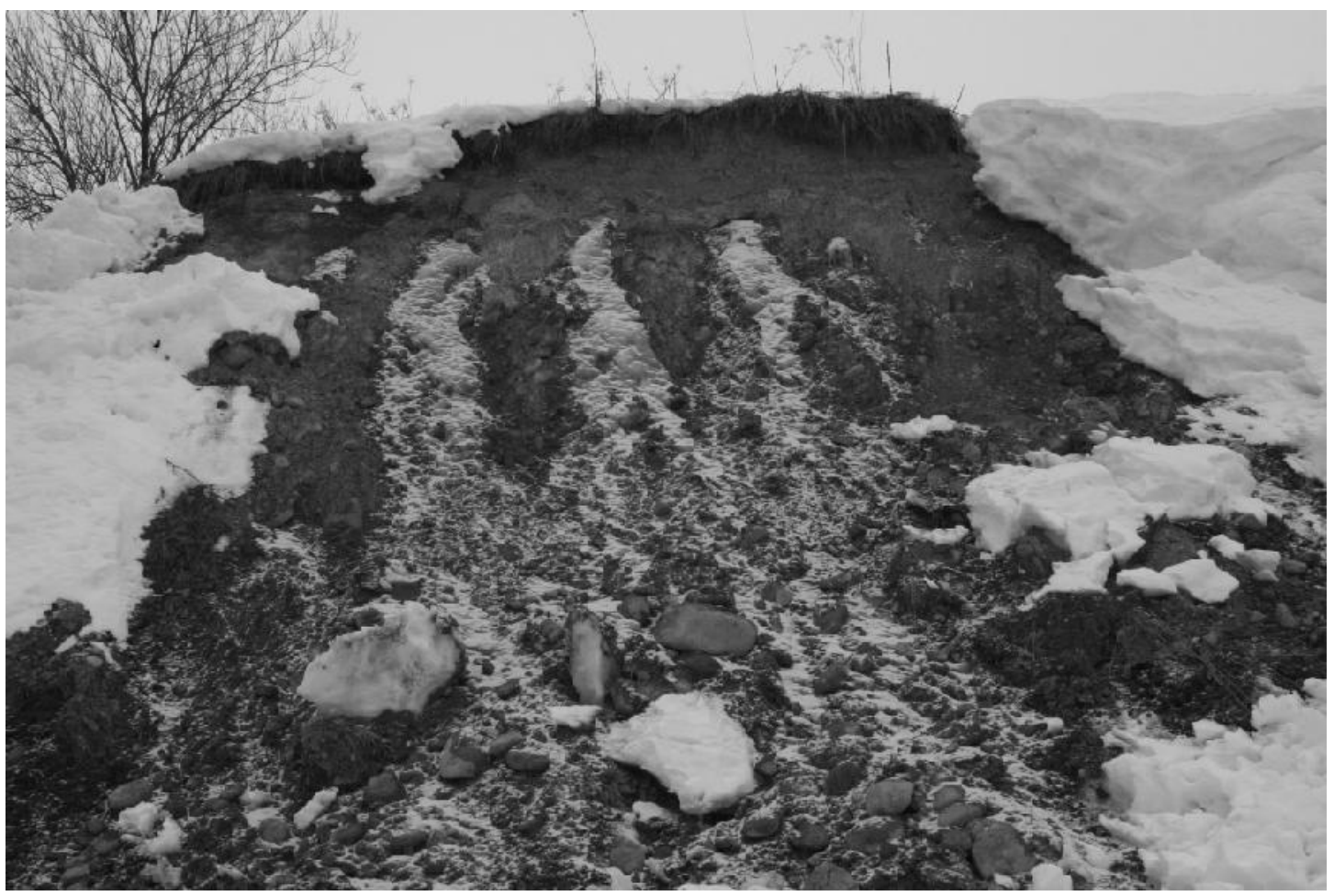

Figure 3. Seepages and bank retreat on the third study site in the basin of Czarny Dunajec.

Major changes in the backflow of the river bank were registered on Czarny Dunajec. In the first multigelation period mostly gravel with a diameter of $2-5 \mathrm{~cm}$ was lost from the bank area. The rest of the waste material was clay. The volume of the talus material exceeded $1 \mathrm{~m}^{3}$. The erosion pins were partially covered by material eroded from the upper part of the bank and deposited in the plane of the pins (tab. 2). During the second period, the amount of eroded material significantly increased. During the study period- the taluses were dominated by rock fragments 5 - $10 \mathrm{~cm}$ in size, without clear segregation. Clay material constituted only $10-15 \%$. The volume of 
the deposited material increased to $4 \mathrm{~m}^{3}$. The third multigelation period involved significant changes in slope surface. Groundwater seepage from the bank surface (fig. 3) and repeated freeze-thaw episodes caused a thin layer of merged clays and gravels, with a residual layer of snow on them to slide downslope. Activated slides of snow and rocky material change the bank face (fig. 4A). In the waste material there were large fragments of sandstone with dimensions of up to $60 \times 20 \times 15 \mathrm{~cm}$. Most of the fragments, however, were smaller and their size ranged from 5 to $15 \mathrm{~cm}$. A large proportion of the material was clay, which, with its plasticity increased by seeping groundwater, became a slip zone for the gravel and rocky material. The volume of waste material increased to $11-12 \mathrm{~m}^{3}$.

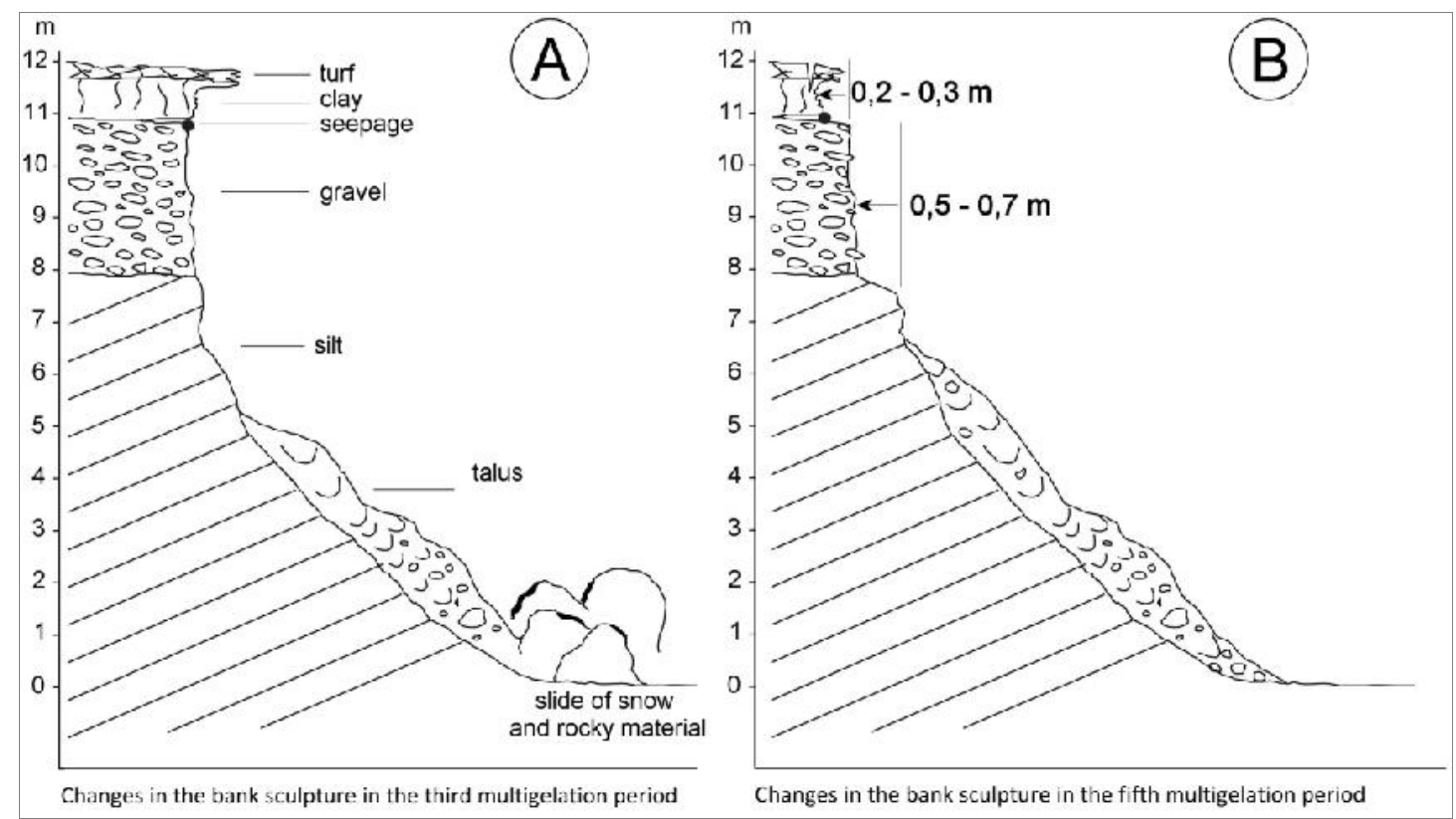

Figure 4. Changes in the bank sculpture and the rate of bank retreat of the Czarny Dunajec river.

Measuring pins were exposed and bank surface retreat occurred at $30-55 \mathrm{~cm}$. During the forth multigelation period no major changes were observed. The volume of falling material increased to about $12-13 \mathrm{~m}^{3}$. Erosion pins were exposed by another $10-15 \mathrm{~cm}$. In the last, fifth observation period, there was slope retreat was greater in the clayey part, while in the first period the slope showed a faster rate of erosion of the layer of gravel. In the course of the autumn-spring season of 2010/2011 the gravel layer of the bank retreated by about $60 \mathrm{~cm}$, and the clay layer by a further $20-30 \mathrm{~cm}$ (fig. 4B). This has been confirmed by the readings of the measuring pins.

\section{Szymbark}

This study site is located on the left bank of the Ropa River which here undercuts a high terrace. The upper part of the bank constitutes a thick $(3 \mathrm{~m})$ layer of fine-grained sandy and silty clay. Lower parts consist of a 2.5-meter layer of gravel, on top of a 2-meter layer of loamy sand and silt. The gravels are quite strongly cemented, with no macroscopically detectable cracks. The clays are poorly consolidated, have thick cracks and pores of biogenic character (fig. 2D). 
The last of the surveyed sites changed in a different way. During the first two multigelation periods the volume of the waste material was very small. It was only clay, with a volume of 0.1 $\mathrm{m}^{3}$. Pins came out by $5 \mathrm{~cm}$ (tab. 2). The third period caused further changes to the bank face. The measuring pins were ejected by $15-20 \mathrm{~cm}$. About $0.2 \mathrm{~m}^{3}$ of clay material was deposited on the layer of gravel, protecting it against frost penetration and formation of needle ice in gravel.. The last multigelation period did not change the surface of the bank. Erosion continued only in the clay fragments. Volume of this material increased to $0.5 \mathrm{~m}^{3}$. Single gravel particles constituted less than $1 \%$ of the waste material. Erosion pins showed bank retreat of 22.4 to $34.2 \mathrm{~cm}$ throughout the autumn-spring season of 2010/2011.

\section{Conclusions}

The obtained data indicate that susceptibility to frost processes at the analysed sites is mainly determined by the grain-size distribution of the bank material. Mud and silty deposits are create better conditions for the penetration of frost and soil swelling. The amount of detached material separated and displaced by gravity down the slope greatly increases with the increasing density of cracks and fractures. On the banks with cemented sandstones and gravels frost action is considerably more selective. First, the fine-grained material is weakening and falling off from bank surface, affecting its stability. In banks made up of poorly consolidated quaternary sediments with grain size is a determining factor in the stability of bank surface. Retreat of flysch banks of occurs somewhat differently. Shale layers are destroyed more rapidly and more often while layers of sandstone lose large block-shaped pieces, but less frequently. Sandstone blocks fall off as a result of the lack of support by the underlying shales. It appears that the rate of retreat of the gravel banks of the rivers in the Podhale is higher than in the Beskid Niski, where the banks are more sandy-muddy. Regularity is apparent in the increasing volume of waste material with increasing grain sizes. It is also noted that frost processes are more active where the banks are not shrubby or wooded. The activity of frost processes within the river banks is spatially uneven. Their effects even at small distances may vary significantly. This follows directly from a mix of local, and even point, complex hydro-geological conditions and temperature.

\section{References}

Allen P.M., Arnold J., Jakubowski E. 1999. Prediction of stream channel erosion potential. Environmental and Engineering Geoscience 3: 339-351.

Casagli N., Rinaldi M., Gargini A., Curini A. 1999. Pore water pressure and streambank stability: Results from a monitoring site on the Sieve River, Italy. Earth Surface Processes and Landforms 24 (12): 1095-1114.

Coffman D. 2009. Streambank Erosion Assessment in Non-cohesive Channels Using Erosion Pins and Submerged Jet Testing. Dallas/Fort Worth, Texas, Ph.D. Thesis.

Couper P.R. 2003. Effects of silt-clay content on the susceptibility of river banks to subaerial erosion. Geomorphology 56: 95-108. 
Couper P.R., Maddock I.P. 2001. Subaerial river bank erosion processes and their interaction with other bank erosion mechanisms on the River Arrow, Warwickshire, UK. Earth Surface Processes and Landforms 26: 631-646.

Couper P.R., Scott T., Maddock I.P. 2002. Insights into river bank erosion processes derived from anaylsis of negative erosion-pin recordings: observations from three recent UK studies. Earth Surface Processes and Landforms 27 (1): 59-79.

Dietrich W.E., Gallinatti J.D. 1991. Fluvial geomorphology. In Slaymaker O. (ed.). Field Experiments and Measurement Programs in Geomorphology. Balkema, Rotterdam, 169-229.

Green T.R., Beavis S.G., Dietrich C.R., Jakeman A.J. 1999. Relating stream-bank erosion to instream transport of suspended sediment. Hydrological Processes 13: 777-787.

Grissinger E.H. 1982. Bank erosion of cohesive materials. In Hey R.D., Bathurst J.C., Thorne C.R. (eds.). Gravel-bed Rivers. John Wiley \& Sons: Chichester, UK, 273-287.

Haigh M.J. 1977. The use of erosion pins in the study of slope evolution. In Shorter Technical Methods (II). British Geomorphological Research Group Technical Bulletin Group 18: 31-49.

Hancock G.R., Murphy D., Evans K.G. 2010. Hillslope and catchment scale soil organic carbon concentration: An assessment of the role of geomorphology and soil erosion in an undisturbed environment. Geoderma 155 (1-2): 36-45.

Hooke J.M. 1979. An analysis of the processes of river bank erosion. Journal of Hydrology 42: 3962.

Hooke J.M. 1980. Magnitude and distribution of rates of river bank erosion. Earth Surface Processes 5: 143-157.

Hupp C.R., Schenk E.R., Richter J.M., Peet R.K., Townsend P.A. 2009. Bank erosion along the damregulated lower Roanoke River, North Carolina. The Geological Society of America, Special Paper 451: 97-108.

Keesstra S.D., Bruijnzeel L.A., van Huissteden J., 2009. Meso-scale catchment sediment budgets: combining field surveys and modeling in the Dragonja catchment, southwest Slovenia. Earth Surface Processes and Landforms 34 (11): 1547-1561.

Knapen A., Poesen J., Grovers G., Gyssels G., Nachtergaele J. 2007. Resistance of soils to concentrated flow erosion: A review. Earth Science Reviews 80: 75-109.

Larsen E.W., Fremier A.K., Greco S.E. 2006. Cumulative Effective Stream Power and Bank Erosion on the Sacramento River, California, USA. Journal of the American Water Resources Association, Paper No. 04232.

Lawler D.M. 1991. A new technique for the automatic monitoring of erosion and deposition rates. Water Resources Research 27 (8): 2125-2128.

Lawler D.M. 1992. Process dominance in bank erosion systems. In Carling P., Petts G.E. (eds.). Lowland Floodplain Rivers. John Wiley \& Sons, New York, 117-143.

Lawler D.M. 1993. Needle ice processes and sediment mobilisation on river bends; the River Ilston, West Glamorgan, UK. Journal of Hydrology 150: 81-114.

Lawler D.M. 1995. The impact of scale on the processes of channelside sediment supply: $a$ conceptual model. In Osterkamp W.T. (ed.). Effects of Scale on Interpretation and Management of Sediment and Water Quality. IAHS Pub. 226. IAHS Press, Wallingford, UK, 175-184. 
Lawler D.M. 2008. Advances in the continuous monitoring of erosion and deposition dynamics: Developments and applications of the new PEEP-3T system. Geomorphology 93: 17-39.

Lawler D.M., Thorne C.R., Hooke J.M. 1997. Bank erosion and instability. In Thorne C.R., Hey R.D., Newson M.D. (eds.). Applied Fluvial Geomorphology for River Engineering and Management. Wiley, Chichester, 137-172.

McDermott J.P., Sherman D.J. 2009. Using Photo-Electronic Erosion Pins for Measuring Bed Elevation Changes in the Swash Zone. Journal of Coastal Research 25 (3): 788-792.

Mitchell S.B., Couperthwaite J.S., West J.R., Lawler D.M. 2003. Measuring sediment exchange rates on an intertidal bank at Blacktoft, Humber Estuary, UK. Science of the Total Environment 314: 535-549.

Prosser I.P., Hughes A.O., Rutherfurd I.D. 2000. Bank erosion of an incised upland channel by subaerial processes: Tasmania, Australia. Earth Surface Processes and Landforms 25: 10111085.

Raudkivi A.J. 1990. Loose Boundary Hydraulics, Pergamon Press, New York, $538 \mathrm{s.}$

Saynor M.J., Loughran R.J., Wayne D.E., Scott P.F. 1994. Sediment movement on hillslopes measured by caesium-137 and erosion pins. Variability in Stream Erosion and Sediment Transport, Proceedings of the Canberra Symposium, December 1994, IAHS Publ. 224: 87-93.

Saynor M.J., Erskine W.D. 2006. Spatial and temporal variations in bank erosion on sand-bed streams in the seasonally wet tropics of northern Australia. Earth Surface Processes and Landforms 31 (9): 1080-1099.

Schumm S.A. 1960. The effect of sediment type on the shape and stratification of some modern fluvial deposits. American Journal of Science 258: 177-184.

Teisseyre A.K. 1984. Procesy fluwialne i rozwój koryta górnego Bobru na odcinku badawczym w Błażkowej. Geologia Sudetica 19 (1): 7-72.

Thorne C.R. 1982. Processes and mechanisms of river bank erosion. In Hey R.D., Bathurst J.C., Thorne C.R. (eds.). Gravel-Bed Rivers, Wiley, Chichester, 227-272.

Thorne C.R. 1990. Effects of vegetation on river bank erosion and stability. In Thornes J.B. (ed.). Vegetation and Erosion. Wiley, Chichester, 125-144.

Thorne C.R. 1992. Bend scour and bank erosion on the meandering Red River, Louisiana. In Carling M.A., Petts G.E. (eds.). Lowland Floodplain Rivers: Geomorphological Perspectives. Wiley, Chichester, 95-116.

Thorne C.R., Osman A.M. 1988. The influence of bank stability on regime geometry of natural channels. In White W.R. (ed.). International Conference on River Regime. Hydraulics Research, Wallingford, 134-148.

Thorne C.R., Tovey N.K. 1981. Stability of composite river banks. Earth Surface Processes and Landforms 6: 469-484.

Walker J., Arnborg L., Peippo J. 1987. Riverbank erosion in the Colville Delta, Alaska. Geografiska Annaler 69A (1): 61-70.

Wallick J.R., Lancaster S.T., Bolte J.P. 2006. Determination of Bank Erodibility for Natural and Anthropogenic Bank Materials Using a Model of Lateral Migration and Observed Erosion Along the Willamette River, Oregon, USA. River Research and Applications 22: 631-649.

Wolman M.G. 1959. Factors influencing erosion of a cohesive river bank. American Journal of Science 257: 204-216. 
Wynn T.M., Mostaghimi S. 2006. The effects of vegetation and soil type on streambank erosion, Southwestern Virginia, USA. Journal of the American Water Resources Association 42: 69-82.

Wynn T.M., Henderson M.B., Vaughan D.H. 2008. Changes in streambank erodibility and critical shear stress due to subaerial processes along a headwater stream, southwestern Virginia, USA. Geomorphology 97: 260-273.

Zaimes G.N., Schultz R.C., Isenhart T.M., Mickleson S.K., Kovar J.L., Russell J.R., Powers W.P. 2005. Stream bank erosion under different riparian land-use practices in northeast lowa. AFTA 2005 Conference Proceedings, 1-10. 